\title{
Kamenná struktura E v Mohelně-Plevovcích: nová výzva pro metodiku výzkumu
}

\author{
Stone structure E at Mohelno-Plevovce: \\ A new challenge for excavation methodology
}

- Jaroslav Bartík*, Petr Škrdla, Tereza Rychtař́iková, Yuri E. Demidenko, Ladislav Nejman -

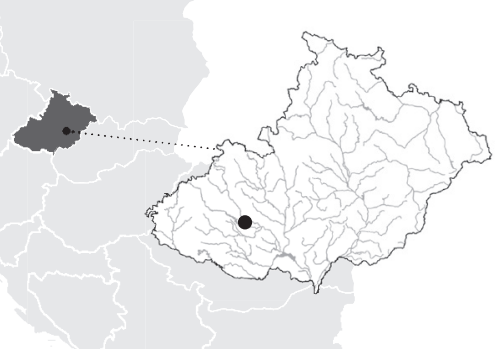

\section{KEYWORDS:}

Mohelno - Late Upper Paleolithic - paved structures -

spatial distribution - site furniture - excavation methodology

\section{ABSTRACT}

A salvage excavation was conducted in harsh conditions to recover stone structure $E$ (KSE). In spite of a very short time window available for digging, an area of $20 \mathrm{~m}^{2}$ was completely excavated and the entire structure (KSE) was carefully documented. Spatial distribution of artifacts closely follows the boundary of the paved area. The raw material spectrum is characterized by prevailing rock crystal, supplemented by quartz, plasma, erratic flint, radiolarite, smoky quartz and Krumlovsky les-type chert. The artifacts are similar to those recovered from KSA and KSB, including carinated atypical endscraper-cores, bipolar anvil cores, and Sagaidak-Muralovka-type microliths. A detailed analysis of granulite used to construct the pavement structure indicates smoothing, abrasion, pounding marks, and flake removals - they probably served as pads for activities that we have not identified as yet.

\section{* Corresponding author -E-mail address: adraj.bartik@gmail.com}

\section{1. Úvod}

Vodní nádrž Mohelno slouží jako vyrovnávací nádrž přečerpávací elektrárny Dalešice a zdroj chladicího média pro Jadernou elektrárnu Dukovany. Přečerpávací elektrárna je využívána jako akumulátor energie, kdy v období přebytku výkonu v síti je voda přečerpávána z VD (vodní dílo) Mohelno do výše položeného VD Dalešice, a v energetické špičce naopak dodává energii do sítě (zdroj ČEZ, a. s.). Toto způsobuje periodické kolísání vodní hladiny na VD Mohelno v rozmezí až 12,4 m (min. nadmořská výška 290,8 m, max. 303,2 m; zdroj Povodí Moravy, s. p.; obr. 1). Kolísající vodní hladina způsobuje erozi kvartérních pokryvných sedimentů na březích a narušuje intaktní archeologické nálezové situace. $\mathrm{Z}$ tohoto důvodu je poloha Plevovce pravidelně sledována povrchovým průzkumem, drobnými sondážemi a systematickými odkryvy již od roku 2011. Objeveny a prozkoumány byly dvě kamenné struktury z období posledního glaciálního maxima (další jsou předmětem tohoto příspěvku), dvě koncentrace nálezů z období pozdního glaciálu (Škrdla et al. 2015; obr. 2: A), dva zahloubené objekty náležící kultuře s moravskou malovanou keramikou (Bartík et al. 2019) a ojedinělé a dosud nestratifikované doklady aktivit v mezolitu/pozdním paleolitu (nepubl.), eneolitu (Škrdla et al. 2012), mladší době hradištní a novověku (Procházka et al. 2019).

Přečerpávací vodní elektrárna Dalešice je důležitou součástí Elektrizační soustavy ČR a energetická bezpečnost ČR má přednost před archeologickým výzkumem. Nelze si tedy objednat odstávku takto důležitého zdroje energie, a je třeba využít plánovaných krátkodobých odstávek z důvodu údržby, jak tomu bylo v minulých letech (podrobně Škrdla et al. 2018). Návštěvy nižších poloh lokality, kde jsou situovány kamenné struktury,

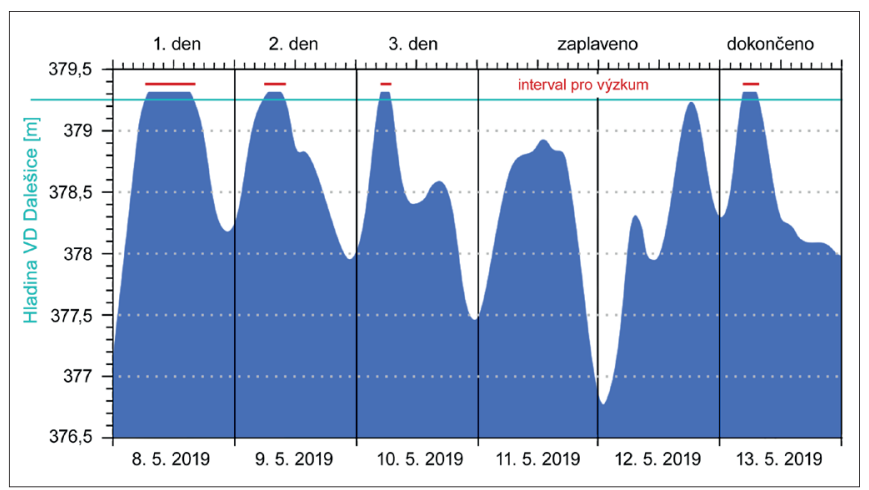

Obr. 1. Kolísání vodní hladiny na základě dat z VD Dalešice. Zdroj: Povodí Moravy [cit. 2019-05-14]. Dostupné z: http://www.pmo.cz/cz/stav/2014/.

Fig. 1. Fluctuation pattern of Vodní dílo Dalešice water level. Source: Povodí Moravy [cit. 2019-05-14]. Available from: http://www.pmo.cz/cz/stav/2014/. 
jsou mimo odstávky možné pouze v brzkých ranních hodinách (v 6 hodin běžně končí přečerpávání do horní nádrže a následně je voda již přepouštěna zpět do spodní nádrže). Ne vždy ale dojde k úplnému vyčerpání až na hladinu minimálního nadržení a prostor se strukturami je tak zaplaven. Tuto skutečnost však nejde dopředu předpovědět, záleží na aktuální energetické situaci, která se může skokově měnit. Navíc v zimním období okolo 6. hodiny ranní není dostatečná viditelnost. Uvedené faktory komplikují sledování a výzkum lokality.

\section{Metodika výzkumu}

Při návštěvě lokality na počátku roku 2019 (leden) byly nedaleko již dříve prozkoumaných kamenných struktur (KSA a KSB) zjištěny vyčnívající kameny a ojedinělé štípané kamenné artefakty. Při detailním ohledání jsme objevili a zdokumentovali další dvě kamenné struktury (KSD a KSE) v místech, kde jejich možnou př́tomnost předpověděl průzkum georadarem v roce 2018 (Škrdla et al. 2019). Po dvou marných pokusech o zdokumentování stavu struktur (byly zaplaveny) se napotřetí (únor 2019) podařilo směrem ke strukturám natáhnout body relativního souřadného systému od struktur KSA a KSB a nové kamenné struktury vynést do celkového plánu lokality (Škrdla et al. 2019, obr. 10; obr. 2: B). Během této návštěvy lokality byla zdokumentována pokračující eroze, která měla za následek obnažování kamenů (dlažby) a vyplavování artefaktů ze struktur. Bylo zřejmé, že bude třeba neprodleně přikročit $\mathrm{k}$ výzkumu struktur, aby nedošlo k jejich výraznému poškození nebo zničení. Přestože odstávka přečerpávací vodní elektrárny Dalešice, byt jen krátkodobá, nebyla pro rok 2019 v plánu, vedení elektrárny nám vyšlo vstříc s možností garance několika termínů, kdy bude voda ve VD Mohelno po tř̌i následující dny vždy mezi 6. a 10. hodinou držena na hladině minimálního nadržení. Rozhodli jsme se této možnosti využít a v květnu jsme realizovali třídenní výzkum ohroženější struktury KSE. Metodiku výzkumu bylo třeba přizpůsobit situaci. Cílem výzkumu bylo očištění nálezové situace (obr. 3: A, B) a zdokumentování kamenné
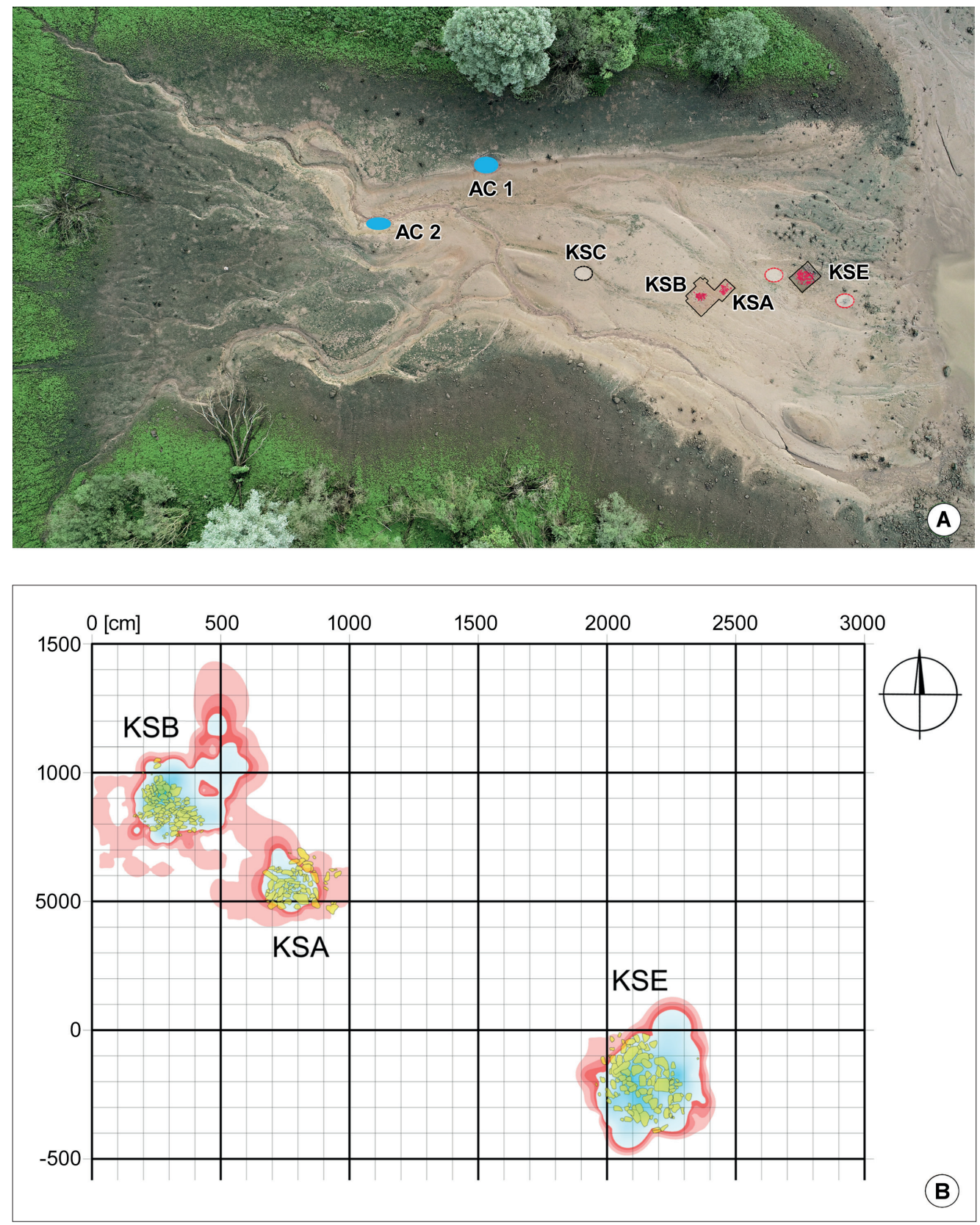

Obr. 2. Pohled na lokalitu $z$ dronu svyznačením zkoumaných koncentrací paleolitických artefaktů (A) a detail zkoumaných kamenných struktur (B). Snímek i grafika T. Rychtaříková.

Fig. 2. Drone view of the site with excavated concentrations of Paleolithic artifacts $(A)$ and detail of excavated stone structures (B). Photo and graphics by T. Rychtaříková. 
struktury (obr. 3: C), zaměření nalezených štípaných kamenných artefaktů, odstranění kamenů struktury a následné prozkoumání sedimentů pod nimi a zároveň proplavení všech překopaných sedimentů, to vše v extrémně omezeném časovém intervalu. Práci komplikovala voda; po poklesu hladiny VD Mohelno byla plocha rozbahněná a při zahlubování byly prohlubně vzápětí zaplňovány vzlínající vodou. Po určité době byla sonda zatopena (obr. 3: D), odpoledne a v noci byla pod hladinou a další den bylo třeba nejprve vybrat vodu ze sondy (obr. 3: E). Sediment na plavení musel být neustále přemístován na vyvýšená místa mimo dosah stoupající hladiny, kde byl postupně proplavován (obr. 3: F, G). Neproplavený sediment musel být transportován do prostoru mimo dosah hladiny (220 m vzdušnou čarou), kde byl pytlován a připraven $\mathrm{k}$ plavení v odpoledních hodinách nebo k transportu mimo lokalitu. První den byla odstávka proti plánu výrazně prodloužena, a naopak poslední den značně zkrácena. Vlastní výzkum byl tak realizován v časovém okně trvajícím 15 hodin. Prozkoumána byla plocha 4,0 × 3,5 m s tím, že část při východním a severním okraji sondy nebyla dokončena z důvodu náhlého vzedmutí hladiny poslední den výzkumu. Na lokalitě jsme setrvali ještě několik dnů, které jsme věnovali plavení sedimentu. Po dva dny se prostor výzkumu nedostal nad hladinu. Až třetí den jsme měli možnost v průběhu dvou hodin výzkum výše zmíněné odkryté plochy dokončit. 60 pytlů sedimentu bylo odvezeno mimo lokalitu a proplaveno v průběhu následujícího měsíce. Jelikož kamenná struktura nebyla zcela vybrána, čemuž nasvědčovaly poznatky z terénu i předběžná analýza půdorysu a rozptylu nálezů, využili jsme další obdobné odstávky v září a v průběhu dalších 3 dnů prozkoumali 4,0 × 1,5 m ve východním směru. Časové okno na vlastní výzkum bylo v tomto prŕpadě 9 hodin. Při této akci bylo získáno dalších 73 pytlů sedimentu k proplavení. V jižním směru nemohl být výzkum dokončen $\mathrm{z}$ důvodu zaplavení lokality.

Jelikož nebylo možné z kapacitních důvodů realizovat výzkum druhé ohrožené struktury (KSD), byla tato překryta ochranným sarkofágem tvořeným okolními sedimenty (z míst
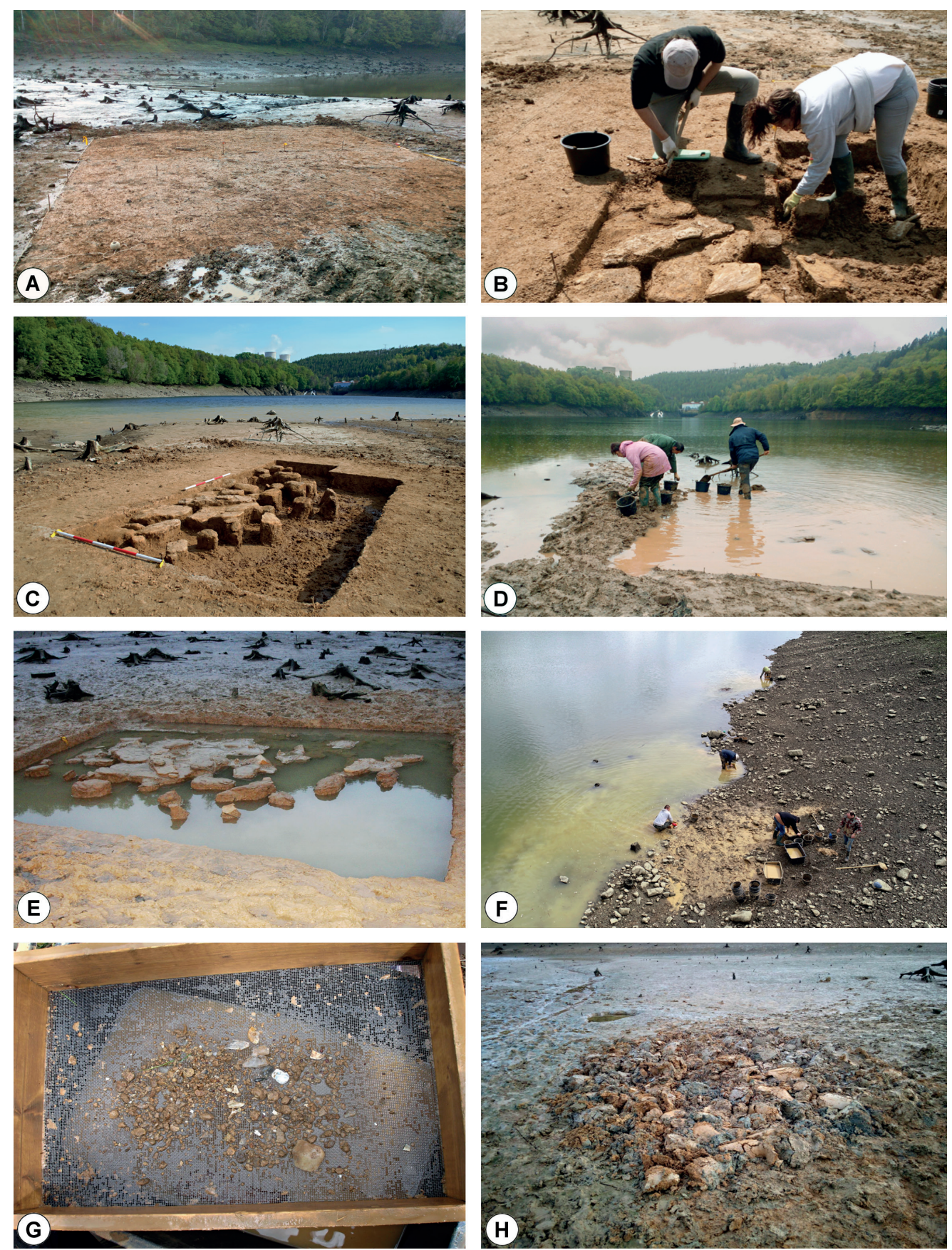

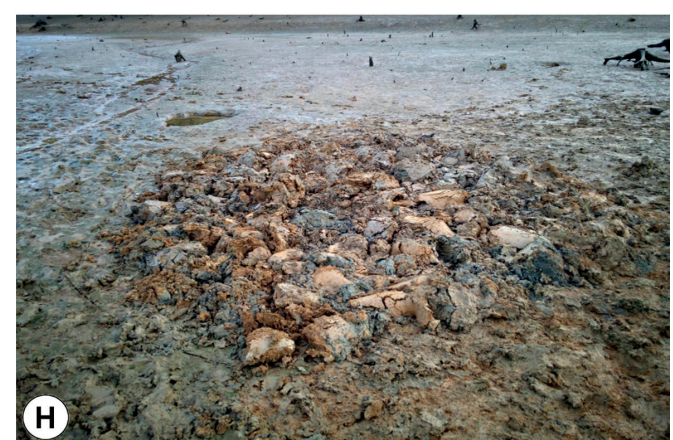

Obr. 3. Pracovní foto z výzkumu. Popis v textu. Foto T. Rychtaříková (A, B, D, F), P. Škrdla (E, G), J. Bartík (C, H).

Fig. 3. Photos of excavation work. Description in text. Photo by T. Rychtaříková $(A, B, D, F)$, P. Śkrdla $(E, G)$, J. Bartík $(C, H)$. 
mimo struktury, tj. bez archeologického materiálu), aby se v co největší míře zabránilo jejímu dalšímu rozplavování do doby, než bude možný její výzkum (obr. 3: H).

Shrneme-li technické parametry, vlastní výzkum byl realizován pomocí špachtlí a motyčky (obr. 3: B) a prozkoumaný materiál byl v desetilitrových vzorcích transportován na plavení. Byly rozlišovány dvě stratigrafické úrovně - vrstva 1: nad kameny a mezi nimi, a vrstva 2: pod kameny (po vyzvednutí dlažby). Všechny artefakty nalezené při tomto výzkumu byly zaměřovány ve dvou horizontálních souřadnicích. Byla prozkoumána plocha $4 \times 5 \mathrm{~m}$ a odebráno přibližně 500 desetilitrových vzorků sedimentu (veškerý prozkoumaný sediment). Tyto vzorky byly $z$ větší části proplaveny na místě, přibližně $1 / 3$ byla transportována k proplavení mimo lokalitu. Použita byla síta o rozměru oka $2 \times 2 \mathrm{~mm}$. Na závěr je třeba zmínit personální zajištění - na realizaci celé akce (všech jejích součástí, tj. výzkumu i plavení) bylo třeba 560 člověkohodin (není započítáno laboratorní zpracování materiálu, tvorba databáze a analýza plošné distribuce).

Díky dronovému snímku začištěné kamenné struktury (pořízenému při první fázi výzkumu; obr. 4) bylo možné s využitím fotogrametrie a digitalizace obrysů vytvořit horizontální plán dlážděné plochy. Zaměřené artefakty a výplavy odlišené v půlmetrové síti nám umožnily studium plošné distribuce artefaktů a jejich vztahu ke dlážděné ploše. Nebylo sice možné sledovat potenciální zahloubení do podloží nebo relikty kủlových jamek, jako tomu bylo v Grubgrabenu ( $c f$. Montet-White ed. 1990; Brandtner, Klíma 1995), ale nutno podotknout, že tyto nebyly zjištěny ani při průzkumech předchozích struktur KSA a KSB, které probíhaly za podstatně archeologicky přívětivějších podmínek. Dno sondy je aktuálně chráněno proti erozi a dochází k jeho postupnému zaplňování sedimenty, které ale mohou být v budoucnu během delší odstávky, kdy dojde alespoň k částečnému vyschnutí sedimentů, odstraněny, a dno sondy může být opětovně začištěno.

Shrneme-li klady a zápory použité metodiky výzkumu, je třeba vyzdvihnout, že kamenná struktura KSE akutně ohrožená erozí byla $\mathrm{v}$ rámci možností prozkoumána, zdokumentována a veškerý archeologický materiál byl zachráněn. Skutečnost, že je KSE poškozována erozí a hrozí její zničení, jsme upřednostnili před možností čekat několik let na větší odstávku, která by ale

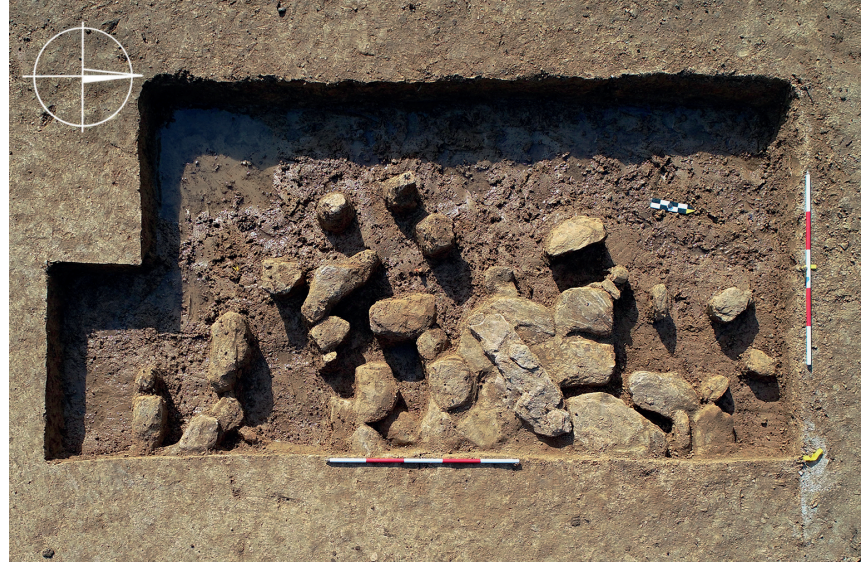

Obr. 4. Začištěná část struktury po prvním dnu výzkumu. Foto T. Rychtaříková. Fig. 4. Cleaned part of the structure at the end of the first excavation day. Photo by T. Rychtaříková.

byla maximálně 5 denní, což by na řádný systematický výzkum stejně nepostačovalo. Prokázali jsme, že použitá metodika intenzivního výzkumu je realizovatelná a může přispět $\mathrm{k}$ záchraně dalších pozůstatků lidského osídlení v daném prostoru. Získané poznatky budou uplatněny při výzkumu kamenné struktury KSD, která je aktuálně částečně chráněná sarkofágem. Alea iacta est!

\section{Planigrafie KSE}

Prozkoumaná struktura KSE byla tvořena 98 kameny vyskládanými v ose severozápad-jihovýchod na ploše 2,8 × 3,6 m. Převládající část struktury sestávala z plochých 2 až $6 \mathrm{~cm}$ mocných desek z místní gföhlské ortoruly, která se díky silnému stupni zvětrání a podmáčenému depozičnímu prostředí značně drolila a měla tendenci k rozpadání už v průběhu exkavace. Velikost desek z ortoruly kolísala od větších, o délce dosahující až $40-50 \mathrm{~cm}$, po menší, s rozměry přibližně $15-20 \mathrm{~cm}$, které vyplňovaly drobné mezery mezi většími kameny. Přibližně jedna pětina kamenné dlažby byla vyskládána z kompaktnějších desek rekrystalizovaného biotitického granulitu a jejich fragmentů. Desky z granulitu jsou sice menších rozměrů (do $25 \mathrm{~cm})$,
Obr. 5. Planigrafie KSE s prostorovým rozložením artefaktů. Grafika T. Rychtaříková.

Fig. 5. KSE planigraphy with spatial distribution of artifacts. Graphics by T. Rychtaříková.

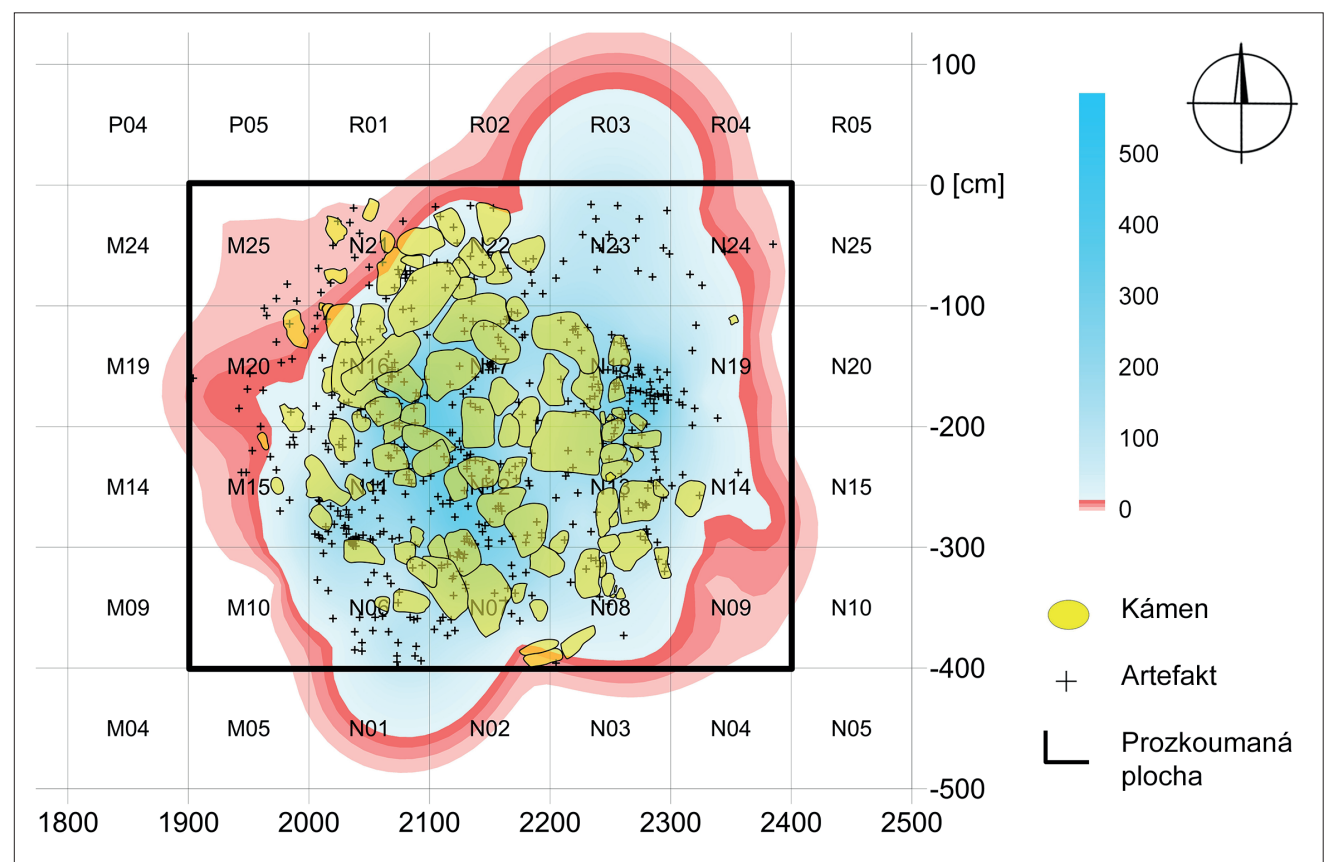


ale v porovnání s deskami ortoruly dosahují větší tlouštky (od 4-15 cm, s průměrem pohybujícím se okolo 7,5 cm). Některé z granulitových desek mírně vyčnívaly nad povrch dlažby, většina ostatních kamenů však utvářela kompaktní rovinu mírně ukloněnou východním směrem (ve směru svahu, obr. 3: E). Surovinové spektrum kamenů tvořících dlažbu doplňují tři menší valouny lokálního amfibolitu, jejichž výskyt byl ve větší míre zaznamenán už při exkavaci dvou předešlých struktur (KSA a KSB). Všechny určené horniny dlažby jsou místní provenience a bylo možné je obstarat v okruhu do $250 \mathrm{~m}$ od zkoumaných struktur (Škrdla et al. 2018, 55). Pokud započteme plochu pokrytí dlažby a průměrnou tlouštku kamenných desek, museli lidé na místo struktury donést materiál o hmotnosti cca 600-700 kg. Dlažba struktury KSE má stejně jako v případě dřive prozkoumaných struktur na zájmové lokalitě nepravidelně obdélníkovitý až mírně lichoběžníkovitý tvar, který doplňuje několik izolovaných kamenů při okraji struktury (obr. 2: B). Pokud jde o rozmístění kamenů, můžeme konstatovat, že až na mírně zvýšený výskyt větších desek v centrální části struktury byla kamenná dlažba sestavena relativně rovnoměrně z kamenů větší i menší velikosti. V jižní polovině struktury byla zjištěna dvě menší místa bez výskytu kamenů (obr. 5). Výzkum $\mathrm{v}$ těchto místech ani nikde jinde pod dlažbou nezjistil intencionálně vzniklé zahloubeniny či kůlové jamky. Absence kamenů v některých místech může být záměrná, ale teoreticky nelze vyloučit ani recentní poškození způsobené rozplavováním struktury vodní erozí ještě před zahájením výzkumu. Na základě dlouhodobého sledování lokality a pravidelných návštěv můžeme konstatovat, že od objevu prvních vyčnívajících kamenů $\mathrm{v}$ roce 2018 nebyla struktura zřejmě výrazněji poškozena.

Z hlediska plošné distribuce je zřejmé, že štípané artefakty byly distribuovány přibližně rovnoměrně v celé ploše dlážděné struktury (obr. 5). Největší koncentrace byla zaznamenána ve východní [2250, -150] a jihozápadní [2125, -225] části struktury. Centrální část kupodivu vykazuje nižší hustotu artefaktů. Jelikož veškerý sediment odebraný ze struktury KSE byl plaven na sítech, bylo získáno 6381 drobných štípaných artefaktů, 822 ks drobných hrudek červeného barviva (o celkové hmotnosti 73,4 g) a více než 300 fragmentů zvírecích kostí a zuboviny. Distribuce drobných artefaktů z výplavů plně koresponduje s rozložením zaměřených artefaktů (obr. 6). Směrem od středu struktury hustota zaměřených i vyplavených artefaktů klesá na nulu a je zde dobře patrná hranice bariéry, jež zamezovala rozptylu artefaktů dále do prostoru. Podobně se bariérový efekt projevoval také u dvou předchozích struktur (Škrdla et al. 2018). Vstup do prostorově ohraničeného prostoru lze předpokládat ze závětrné severovýchodní strany, kde rozptyl nálezů přesahuje plochu samotné dlažby (obr. 5).

\section{Suroviny}

V rámci výzkumu kamenné struktury KSE bylo nalezeno celkem 526 artefaktů. Převážnou většinu tvořily artefakty vyrobené z křiš̌tálu (48,5\%), následované křemenem (22,8\%) a plazmou (20,0\%). Ostatní suroviny - eratický silicit, radiolarit, rohovec typu Krumlovský les a záhněda - se vyskytly v řádu několika procent (tab. 1). Lokální suroviny zastoupené křištálem, křemenem a plazmou tak představují více než 91 \% celého souboru a jsou jen okrajově doplněny surovinami regionálního významu (rohovec typu Krumlovský les a záhněda; celkem $1,5 \%)$ a vzdálenějšími importy v podobě eratického silicitu a radiolaritu (7,2\%).

\begin{tabular}{llll}
\hline & KSA & KSB & KSE \\
\hline $\begin{array}{l}\text { rohovec typu Krumlovský les - } \\
\text { Krumlovský les-type chert }\end{array}$ & 0 & 10 & 4 \\
\hline radiolarit - radiolarite & 3 & 5 & 16 \\
\hline eratický silicit - erratic silicite & 31 & 29 & 22 \\
\hline křištál - rock crystal & 13 & 280 & 255 \\
\hline křemen - quartz & 22 & 82 & 120 \\
\hline $\begin{array}{l}\text { plazma - siliceous weathering product } \\
\text { of serpentinite, plasma type }\end{array}$ & 1 & 35 & 105 \\
\hline záhněda - smoky quartz & 1 & 0 & 4 \\
\hline neurčeno - not identified & 2 & 0 & 0 \\
TOTAL & 73 & 441 & 526
\end{tabular}

Tab. 1. Suroviny štípané kamenné industrie (bez drobných nálezů). Tab. 1. Raw materials of knapped industry (excluding small finds).

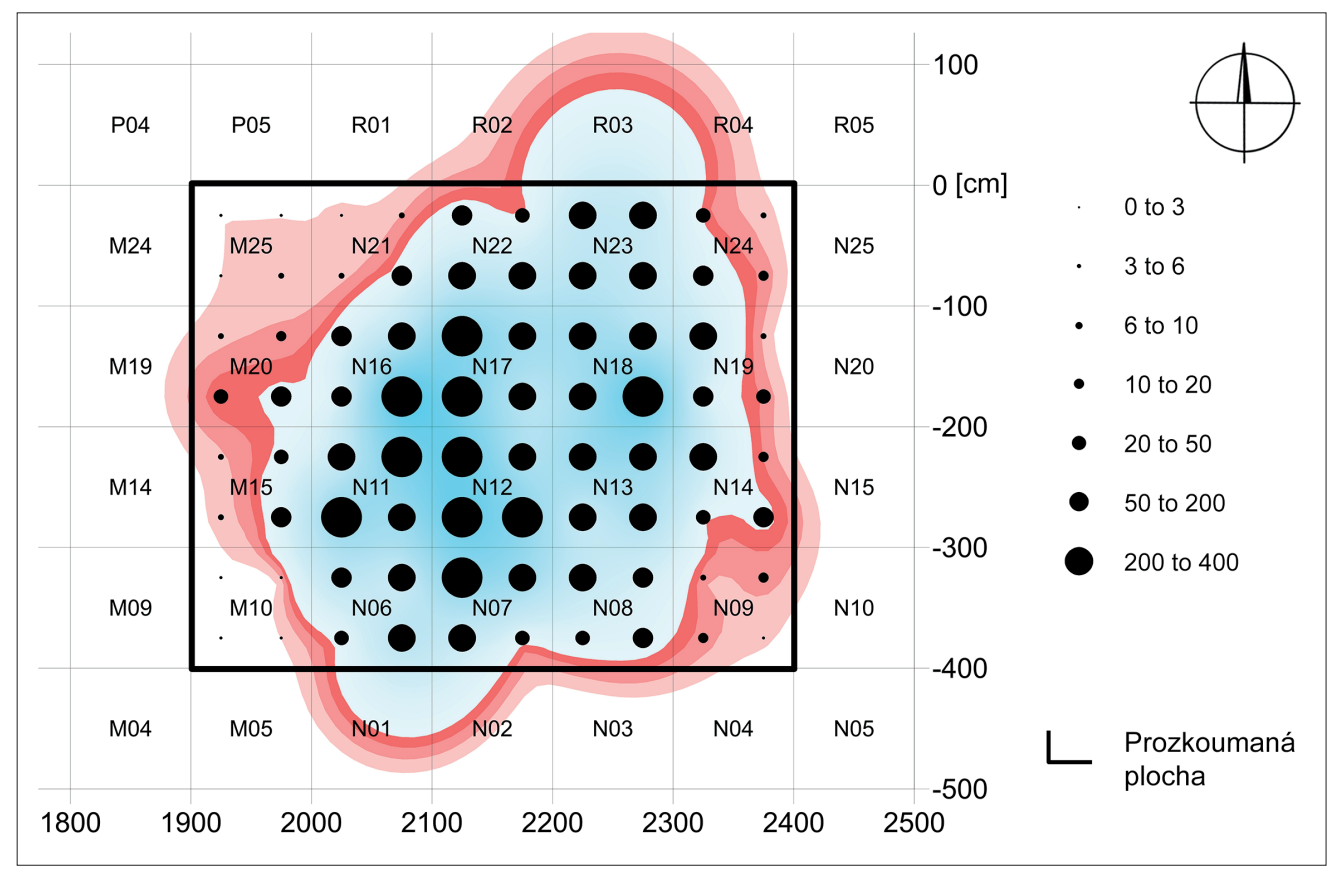

Obr. 6. Poměrné kruhy ukazující hustotu artefaktů vjednotlivých sektorech. Grafika T. Rychtař́íková. Fig. 6. Classed post showing artifact density within individual sectors. Graphics by T. Rychtaříková. 


\section{Technologie a typologie}

Analyzovány mohou být, podobně jako v př́ípadě surovin, zatím pouze artefakty inventarizované $(526 \mathrm{ks})$. Drobné artefakty z výplavu (6 381 ks) zatím čekají na detailní zpracování.

Kolekce je opět, jako již dříve hodnocené soubory ze struktur KSA a KSB, výrazně úštěpová (cf. Škrdla et al. 2016) - úštěpy představují 70,4 \% souboru. Oproti předchozím kolekcím jsou ale v př́ípadě KSE výrazněji zastoupena jádra (včetně mikrojader tvoří 7,2\% souboru, exemplář na obr. 7: 26 byl zřejmě reutilizován na otloukač) a čepele (včetně zlomků a mikročepelí - 7,0 \%). Opět se hojně vyskytují „odštěpovače“ (obr. 7: 23, 24, 27), které však ve většině př́ípadů sloužily spíše jako jádra na polotovary mikrolitů, a z tohoto důvodu nebyly v aktuální klasifikaci zahrnuty mezi nástroje (bipolar anvil cores - 4,2\%).

Dvacet pět nástrojů, které se aktuálně podařilo rozpoznat, představuje 4,5 \% kolekce. Další velký soubor nástrojů budou představovat mikrolity (mezi inventovanými artefakty je pouze jeden kus, obr. 7: 1), které budou dodatečně vytř́íděny z výplavů. Jelikož tento proces je časově náročný (vzhledem k miniaturním rozměrům mikrolitů je třeba každý mikrolit identifikovat pod lupou), jejich vytřídění dosud nebylo dokončeno (aktuálně víme již o více než 40 mikrolitech, analyzována ale dosud byla jen přibližně třetina kolekce). Stejně tak nelze vyloučit, že ve výplavech budou identifikovány ještě nějaké další nástroje malých rozměrů. Převládajícím typem nástroje v aktuálním souboru je škrabadlo (všechny jejich typy dohromady představují téměř $2 / 3$ kolekce nástrojů).

Objevují se ploché exempláře vyrobené na krátkých úštěpech (obr. 7: 6, 7, 10-12), v jednom př́padě na větším úštěpu (téměř dosahuje metriky čepele, obr. 7:28), ale u řady dalších, zejména masivnějších exemplářů (obr. 7: 2-5, 9, 13, 25), je zřejmé, že jde spíše o jádra na drobné karenoidální odštěpky, které v kolekci běžně představují polotovary mikrolitů. Propojení či překrývání těchto kategorií (tj. atypických karenoidálních škrabadel a mikrojader) dokládá i traseologická analýza předchozích souborů, kdy škrabadlo, které nese stopy po zpracování kủže, bylo běžně reutilizováno na jádro na polotovary mikrolitů (Rios-Garaizar et al. 2019).

Třemi kusy jsou zastoupena rydla (dvě jednoduchá hranová na do hrotu retušované hraně - obr. 7: 19, 21 a rydlo klínové na hrotitě retušovaném úštěpu - obr. 7: 20) a třemi drobné, ale masivní zobce (obr. 7: 16-18; u jednoho z nich je patrný negativ karenoidálního úštěpku - obr. 7: 16). Kolekci nástrojů uzavírají dvě př́čně konkávně retušované čepele (obr. 7: 14, 15), atypický hrot (impaktem poškozený artefakt - obr. 7: 22) a mikrolit (obr. 7: 1). Nebyla pozorována výraznější preference určité suroviny na určitý typ nástroje, jen vyšší výtěžnost na nástroje v př́ípadě eratického silicitu, a naopak nižší u křemene a křištálu (v porovnání s celkovým surovinovým spektrem).

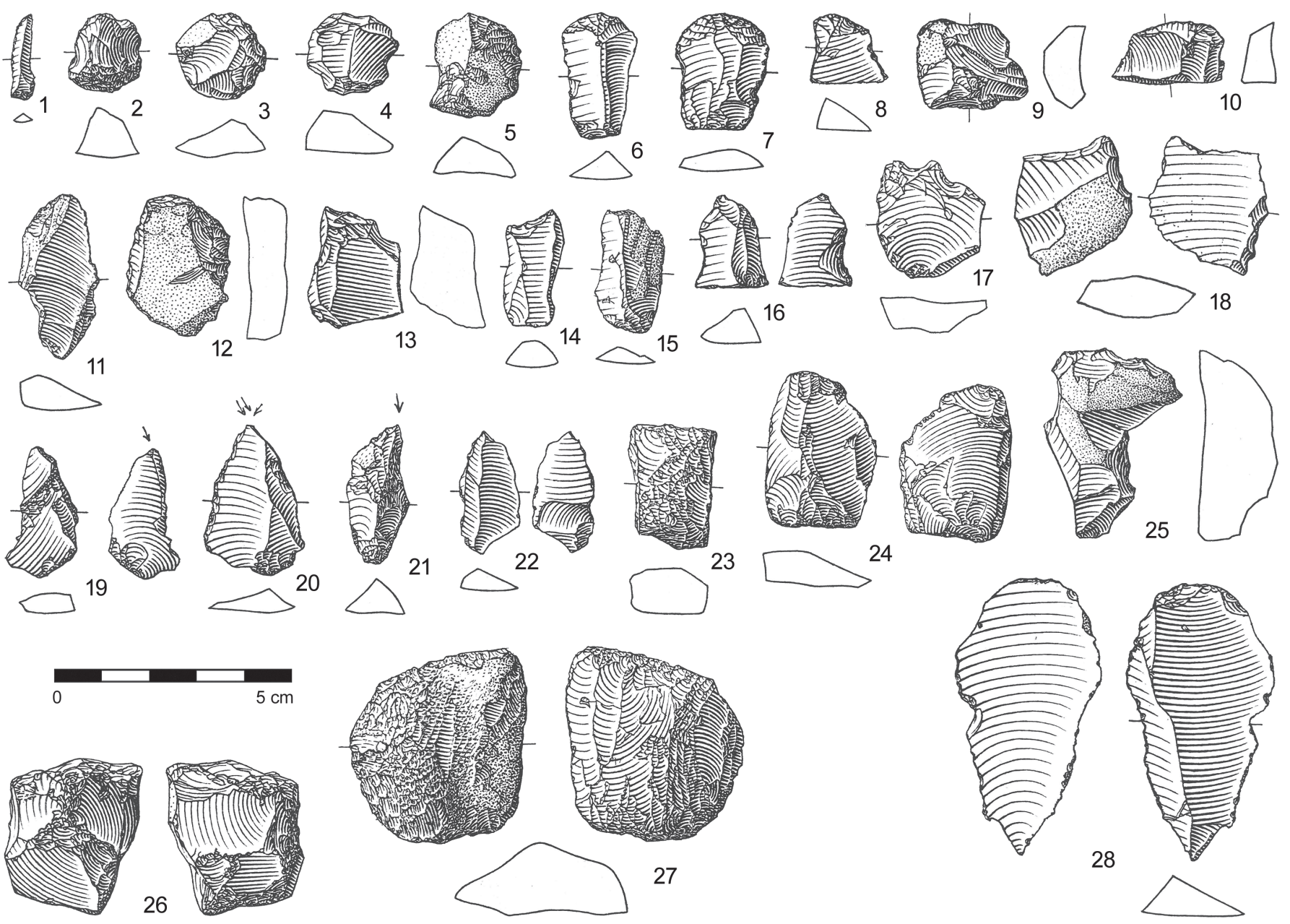

Obr. 7. Vybrané artefakty. Suroviny: křištál (1, 2, 5, 9-13, 15, 21, 23, 24, 27), křemen (13), eratický silicit (3, 6-8, 16, 20, 26, 28), plazma (4, 17, 18), radiolarit $(19,22)$, rohovec typu Krumlovský les $(25)$. Kresba J. Brenner.

Fig. 7. Selected artifacts. Raw materials: rock crystal (1, 2, 5, 9-13, 15, 21, 23, 24, 27), quartz (13), erratic silicite (3, 6-8, 16, 20, 26, 28), siliceous weathering product of serpentinite, plasma type $(4,17,18)$, radiolarite $(19,22)$, Krumlovský les-type chert (25). Drawing by J. Brenner. 


\section{Hrubotvará kamenná industrie}

Spektrum štípaných artefaktů, drobných zlomků barviva a zvířecích kostí z KSE doplňuje poměrně početná kolekce hrubotvaré kamenné industrie čítající téměř sedm desítek kusů. Představuje zřejmě součást pevné výbavy sídliště (site furniture) ve smyslu L. Binforda (1979). Tato kategorie mohla být vyčleněna až na základě analýzy materiálu z KSE, a představuje proto nový směr ve výzkumu kamenných struktur. Obecně jsou do této skupiny nástrojů zahrnovány artefakty z hrubých surovin nebo neštípané artefakty často větších tvarů. Surovinou je většinou granulit, amfibolit a křemen. Tyto artefakty můžeme třídit do skupin podle surovin nebo funkce. Obě hlediska jsou ale vzájemně propojena, existuje zřejmě závislost mezi funkcí a surovinou - např́iklad desky a podložky jsou vyrobeny převážně z granulitu a amfibolitu (obr. 9), zatímco otloukače a drtiče převážně z křemene (ale křemenné valouny mohly sloužit též jako podložky - obr. 8). Je možné, že část podobných artefaktů (s výjimkou křemenných) ze struktur KSA a KSB nebyla rozpoznána (identifikovány byly ovšem ploché amfibolitové valouny). Taktéž je možné, že jako podložky sloužily i desky z ortoruly, jejichž povrchy jsou zvětralé do té míry, že analýzu znemožňují. Využití kamenů, které byly součástí dlažby, pro široké spektrum činností bylo již dříve konstatováno na podobně datované lokalitě Grubgraben (Montet-White, Williams 1994).

Z typologického hlediska můžeme tyto artefakty dále členit do několika samostatných funkčních skupin. První a zároveň nejpočetnější skupinu tvoří předměty z granulitu, které kromě toho, že byly integrální součástí dlažby, plnily i mnoho dalších rozličných funkcí, což dokládá široké spektrum pracovních stop, které se podařilo identifikovat na jejich povrchu. Rozpoznány byly granulitové desky s pracovními plochami (14 ks) a jejich zlomky (23 ks), ale i regulérní úštěpy s dobře viditelnými bulby (14 ks; obr. 9: 5-7). Také na tuto část industrie jsme aplikovali metodu zpětného skládání, které bylo nad očekávání úspěšné. Celkem se podařilo zpětně sestavit 6 skládanek, obsahujících 2 až 6 částí. Zpětné skládání odhalilo několik zajímavých struktur. Za nejzajímavější lze považovat fakt, že převážná část větších granulitových desek je ve fragmentárním stavu, přesto se je ale mezi sebou nepodařilo skládat. Z toho vyplývá, že $\mathrm{k}$ jejich rozbití došlo už na jiném místě a až posléze byly doneseny do prostoru KSE. Na uvedené větší desky je ovšem možné přikládat menší úštěpy, které byly zpravidla odraženy z hran v místě lomu, kde byla deska poškozena (obr. 9: 4). Dále se podařilo poskládat torza dvou menších plochých destiček (obr. 9: 2, 3). Jak už bylo naznačeno výše, téměř všechny granulitové desky nesou na povrchu pracovní stopy. Běžně se zde vyskytují i desky s více pracovními plochami kombinujícími různé směry (včetně protilehlých) i různé druhy opotřebení. Identifikovat se podařilo zejména ohlazení povrchu, které mohlo dosahovat i značné intenzity a které mělo za následek mírně sedlovité prohnutí pracovní plochy. Někdy je vyhlazení či zdrsnění povrchu lokalizováno do oválných či nepravidelně tvarovaných útvarů, které jsou oproti okolní ploše desky zahloubeny až o několik milimetrů (obr. 9: 8). Další prokázané pracovní stopy představují drobné důlky a kaverny v povrchu vzniklé bud’to opakovanými silnými údery, nebo v několika prŕpadech i opakovaným třením v jednom místě. Detailní analýze determinovaných skládanek a pracovních opotřebení bude po provedení validačních mikroskopických pozorování věnována pozornost v další studii. Je evidentní, že granulitové desky představovaly multifunkční nástroje, které byly využívány především $\mathrm{k}$ drcení a roztírání nejrůznějších organických i anorganických materiálů. Sekundárně pak mohly rozbité desky sloužit i jako jádra, ze kterých byly získávány hrubší úštěpy, jež mohly být dále využívány (situational gear, expedient tools; $c f$. Binford 1979). Opakované používání desek na různých plochách a způsob jejich postupné destrukce nasvědčuje, že mohly být přenášeny mezi strukturami a reutilizovány při opětovných
Obr. 8. Hrubotvará industrie $z$ křemene: rozbité otloukače (1, 2), chopper/jádro (3). Kresba J. Brenner. Fig. 8. Heavy-duty industry made of quartz: fragmented hammerstones (1, 2), chopper/core (3). Drawing by J. Brenner.
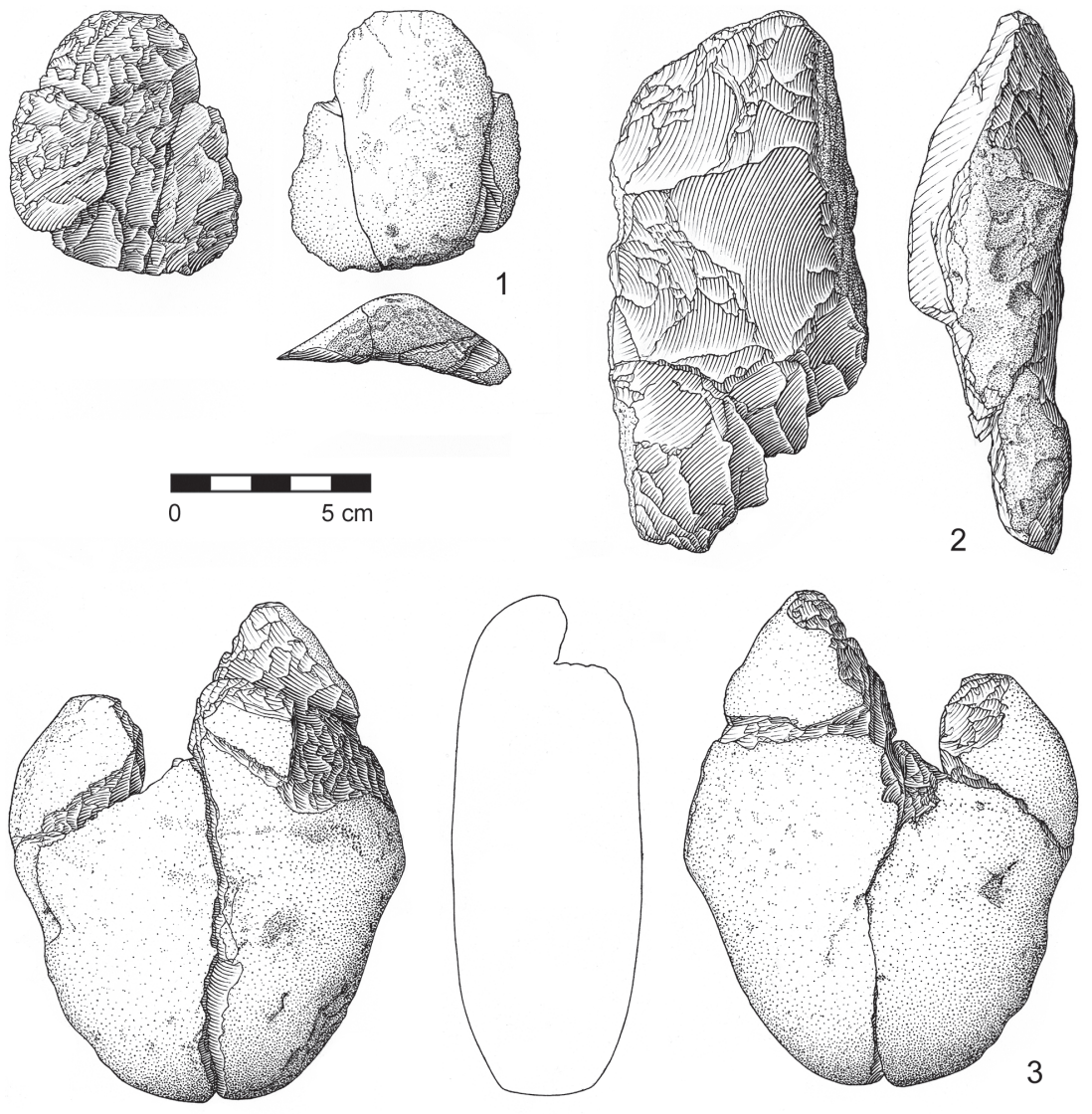

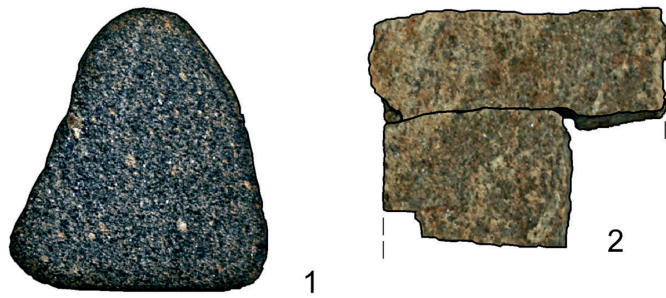

1

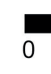

0

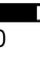

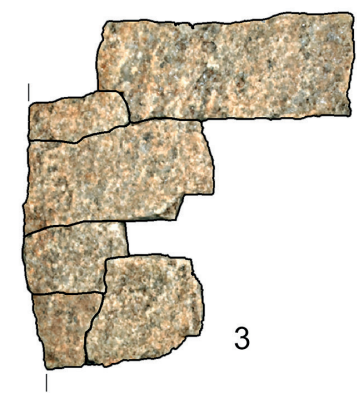

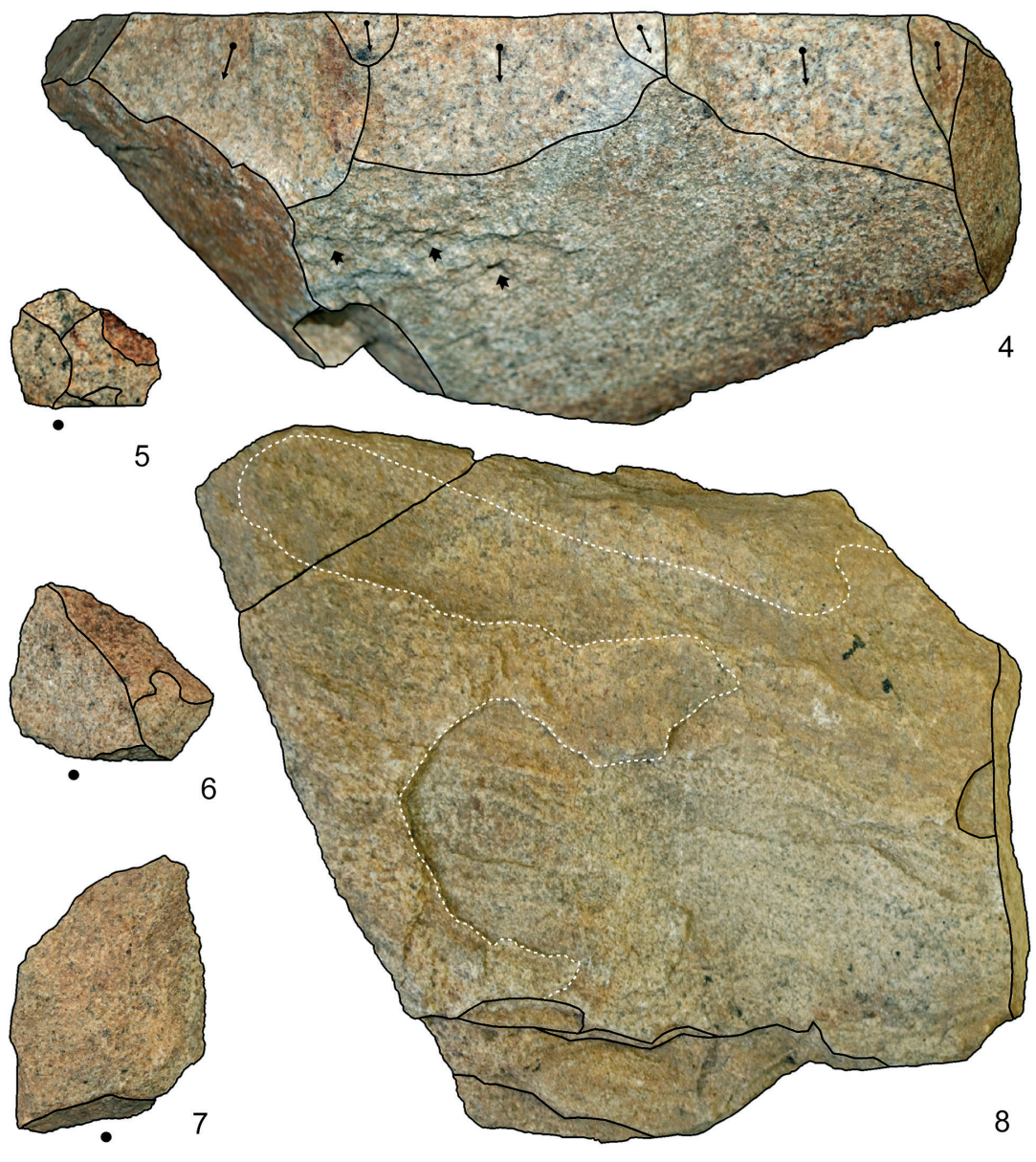

Obr. 9. Výběr hrubotvaré kamenné industrie. Suroviny: 1 - amfibolit; 2-8 - granulit. Znaky: černé šipky značí směr odbití úštěpů a pozici stop po úderech; bílá přerušovaná čára vymezuje zahloubené plochy s ohlazeným povrchem. Foto a grafika J. Bartík.

Fig. 9. Selection of the heavy-duty industry. Raw material: 1 - amphibolite; 2-8-granulite. Symbols: black arrows indicate direction of removals; the interrupted white line defines depressions with smoothed surface. Photo and graphics by J. Bartík. návštěvách lokality (site furniture; $c f$. Binford 1979). Tento předpoklad však bude nutno validovat dalšími výzkumy. Pokud jde o prostorovou distribuci úštěpů a zlomků z granulitu, můžeme pozorovat jejich výskyt především v centrální a severozápadní části struktury, což částečně kontrastuje s výskytem větších desek spočívajících převážně v jižní polovině struktury KSE. Tento jev může do jisté míry podporovat teorii o jejich využití $k$ dalším činnostem na jiném místě struktury.

Druhou funkční skupinu makrolitické industrie reprezentují artefakty z valounů. Po surovinové stránce se vážou na dva lokální materiály - amfibolit a křemen. Z amfibolitu je drobná plochá destička ve tvaru rovnoramenného trojúhelníku se zaoblenými rohy, jejíž svrchní plocha je oproti zbytku povrchu výrazněji ohlazena (obr. 9: 1). Prokazatelné stopy užívání nese rovněž poškozený plochý valoun oštípaný ze dvou stran, přičemž některé odštěpy zabíhají výrazněji do jeho plochy. Na levé boční straně zůstal zachován původní naturální povrch, v horní části hrany je však patrné zhmoždění a několik drobnějších úštěpů. $Z$ druhé strany je valoun díky úpravě osekáním velmi dobře uchopitelný, což dovoluje artefakt interpretovat jako masivní sekáč/drtič k rozbíjení a drcení kostí či jiných materiálů. Soubor dále obsahuje 6 drobných valounků křemene a jeden oblázek křištálu se stopami červeného barviva na povrchu. Valounky mají zpravidla oválný, popřípadě nepravidelně oválný tvar o průměru mezi 3-4 cm a do prostoru struktury byly doneseny člověkem. Na většině z nich byly makroskopicky identifikovány pracovní stopy. Na jednom se objevil drobný úštěp na užší straně a ve dvou případech nese valounek nevýrazné stopy odrcení na obou protilehlých bocích. Je možné, že některé valounky sloužívaly jako abradéry nebo jako retušéry při výrobě nástrojů.

Křemenné valouny byly zřejmě primárně využívány ve funkci otloukačů. Zajímavé je, že pouze jediný otloukač se dochoval kompletní. Dalších 5 exemplářů je ve zlomcích, přičemž u některých se podařilo $\mathrm{v}$ rámci zpětného skládání artefaktů sestavit pouze plášť otloukače sestávající z několika na sebe přiložených úštěpů (obr. 8). Kolekce obsahuje i další zhmožděné křemenné úštěpy, které by mohly pocházet $\mathrm{z}$ otloukačů. Byly však z technologického pohledu klasifikovány jako štípaná industrie, jelikož je vysoce pravděpodobné, že rozbité otloukače byly sekundárně využívány jako jádra. Stejný problém se týká klasifikace masivního chopperu z křemene $\mathrm{s}$ přiloženou sérií krátkých úštěpů, který však může být zároveň úštěpovým jádrem (obr. 8: 3). Kolekci uzavírá několik hrubých jader na úštěpy. 


\section{Fauna}

Při výzkumu bylo získáno více než 300 zlomků zvírecích kostí a zuboviny. Nejvíce pozůstatků patří blíže neidentifikovatelným drobným fragmentům o velikosti 1-5 mm. Některé jsou spálené a jejich barva je černá až šedobílá, což ukazuje na teplotu ohně pohybující se mezi $500-600^{\circ} \mathrm{C}$. Nejvíce identifikovatelných pozůstatků patř́i koni sprašovému (Equus ferus germanicus). Celkem byly určeny fragmenty ze třech molárů, dvou horních (molares 1-2) a jednoho spodního (molar 1-2). Další fragment stoličky (molar) patří sobu polárnímu (Rangifer tarandus). Oba výše uvedené druhy jsou zastoupeny pouze jedním jedincem. Spektrum fauny odpovídá dřívějším nálezům (Škrdla et al. 2016) a ukazuje na prostřredí chladné stepi.

\section{Závěrečné úvahy}

Při výzkumu KSE byla v několika etapách odkryta plocha $5 \times 4 \mathrm{~m}$. Záměrem bylo odkrýt celou dlážděnou strukturu, což se zřejmě podařilo. Nelze ale zcela vyloučit, že další izolované kameny budou ještě v sousedních sektorech. Analýza plošné distribuce naznačuje, že nálezy by mohly v některých místech na severním a jižním okraji sondy pokračovat i mimo dlážděnou plochu, jak tomu bylo v př́ípadě KSB. Podobný je i přesah nálezů v severovýchodním směru. Plochu výzkumu tak bude ještě nutné rozšíritit a v tomto příspěvku uváděné počty nálezů tak zřejmě ještě nejsou definitivní.

Technologické spektrum KSE je oproti KSA a KSB poněkud pestřejší - objevují se v něm větší jádra i mikrojádra a dále pak také artefakty metricky spadající do kategorie čepelí a mikročepelí. Po typologické stránce je soubor z KSE obdobný předchozím strukturám KSA a KSB - převažují škrabadla. Podíl mikrolitů nelze dosud porovnat.

Surovinové spektrum KSE (tab. 1, obr. 10) je obdobné struktuře KSB, kde je též majoritně zastoupen lokální křrištál v doprovodu křemene a plazmy (celkem 90,1 \%) a regionální a importované suroviny se vyskytují v rámci několika procent (rohovec typu Krumlovský les - 2,2 \%; radiolarit a eratický silicit - 7,7\%). Naopak ve struktuře KSA je podíl lokálních (křištál, křemen a plazma - 49,3\%) a importovaných surovin (eratický silicit, radiolarit - 46,6\%) téměř vyrovnaný a regionální suroviny jsou zastoupeny pouze jedním kusem záhnědy (u dvou artefaktů nebyla surovina rozeznána). V kolekci z KSE se oproti KSA a KSB vyskytl velmi kvalitní a čistý křištál s dobře vyvinutými krystalovými plochami, který spolu s př́ítomností krystalické záhnědy naznačuje, že lidé z Plevovců mohli proniknout i ke zdrojům křištálu hlouběji v Českomoravské vrchovině (horní Pooslaví, přibližně 40 km od Mohelna; cf. Slobodník, Přichystal 2017).

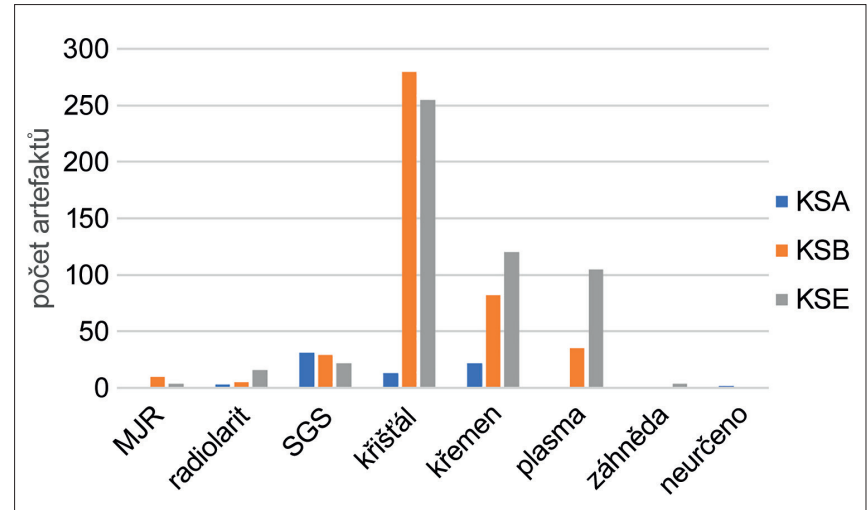

Obr. 10. Porovnání podílů surovin v jednotlivých kamenných strukturách. Grafika T. Rychtaříková.

Fig. 10. Comparison of raw material spectra for individual stone structures. Key: see table 1. Graphic by T. Rychtaříková.
Významné poznatky přinesl výzkum struktury KSE především z pohledu dokladů rozličných sídlištních aktivit spojených s využíváním makrolitických kamenných artefaktů. Vysoké zastoupení hrubotvaré industrie otevírá zcela nové možnosti studia zdejších lidských aktivit. Oproti předchozím zkoumaným strukturám obsahovala KSE vyšší počet granulitových desek, z nichž převážná většina nese známky pracovních stop v podobě ohlazení či obití. Je možné, že některé z desek v rámci KSA či KSB obsahovaly tytéž makroskopické stopy, avšak nebyly identifikovány. Spolehlivě však byl ve všech strukturách zaznamenán výskyt plochých amfibolitových valounů. Za pozornost stojí zejména jedna amfibolitová deska rozbitá na několik kusů, jež byla vyzvednuta při výzkumu KSB a která nese možné náznaky užívání. Předběžná analýza hrubotvaré industrie z KSE prokázala, že velké rozbité granulitové desky mezi sebou nelze až na výjimky skládat, což může ukazovat na jejich pohyb v rámci sídliště a možnost opakovaného použivání při periodických návštěvách lokality. Vícefázové užívání je ostatně patrné na většině granulitových desek, kde se objevují běžně vícečetné nebo dokonce protilehlé pracovní plochy. Doloženy byly skládanky úštěpů a zlomků odražených z těchto desek a také částečné složení dvou drobných plochých destiček, jež měly patrně jiný primární účel než velké masivní desky. Kromě desek sloužících jako multifunkční podložky k drcení, roztírání a štípání nejrůznějších materiálů (je pravděpodobné, že sloužily i jako podložky při aplikaci techniky bipolar anvil cores) byly determinovány také valounové otloukače z křemene a jejich fragmenty, stejně jako i drobné valounky sloužící snad jako abradéry či retušéry. Bližší pochopení skutečné funkce jednotlivých artefaktů bude možné až po provedení detailních traseologických a prostorových analýz, které budou jedním z hlavních cílů následného výzkumu.

Výzkum struktury KSE lze charakterizovat jako výzkum vedený s maximální intenzitou, aby ho bylo možné realizovat v omezeném časovém úseku. Přestože je charakterizován jako záchranný, je snaha o aplikaci maximálního počtu parametrů výzkumu systematického. Tímto se zásadně odlišuje od metodických postupů běžně aplikovaných při záchranném výzkumu, které spočívají často jen v hrubém vzorkování nálezových situací a jejich rámcovém kulturním zařazení. Nikoliv tedy skutečné záchraně či prohloubení vědeckého poznání. Abychom se od těchto zvyklostí distancovali, navrhujeme pro tento typ výzkumu označení výzkum záchranně-systematický, což nejlépe vystihuje - i za ztížených podmínek - snahu nejen o záchranu, ale i o maximální možnou míru aplikace metodiky výzkumu systematického v prostředí výzkumu záchranného.

\section{Poděkování}

Výzkum vznikl s institucionální podporou na dlouhodobý koncepční rozvoj výzkumné organizace RVO: 68081758 - Archeologický ústav AV ČR, Brno, v. v. i. Zpracování materiálu a analýzu podpořila dotace AV ČR na podporu nositele titulu doktor věd.

\section{Literatura}

Bartík, J., Škrdla, P., Novák, J. 2019: Mohelno-Plevovce v kontextu lokálního lengyelského osídlení a přírodního prostředí. Přehled výzkumů 60(1), 43-76.

Binford, L. R. 1979: Organization and formation processes: looking at curated technologies. Journal of Anthropological Research 35(3), $255-273$.

Brandtner, F., Klíma, B. 1995: Überlegungen zu einer Rekonstruktion der Behausung der paläolithstation „Grubgraben“ bei Kammern; NÖ. In: F. F. Steininger, H. Reinhart (eds.): Katalog zur Sonderausstellung: Schamanenzauber und Eiszeitkunst. Katalogreihe des Kraluletz Museums 14. Eggenburg: Kraluletz Museum, 45-50. 
Montet-White A. (ed.) 1990: The Epigravettian Site of Grubgraben, Lower Austria: the 1986 and 1987 Excavations. Études et recherches archéologiques de l'Université de Liège 40. Liège: Service de préhistoire, Université de Liège.

Montet-White A., Williams, J. T. 1994: Spatial Organization at a Winter Campsite of the Last Glacial Maximum: The Case of Grubgraben AL1. Journal of Anthropological Archaeology 13(2), 125-138.

Povodí Moravy: Detail měřícího bodu: Dalešice [online]. (2010-2020 [cit. 2019-05-14]. Dostupné z: http://www.pmo.cz/cz/stav/2014/.

Procházka, R., Škrdla, P., Žákovský, P. 2019: Mohelno (okr. Třebíč). Přehled výzkumu 60(2), 286-287.

Rios-Garaizar, J., Škrdla, P., Demidenko, Yu. E. 2019: Use-wear analysis of the lithic assemblage from LGM Mohelno-Plevovce site (southern Moravia, Czech Republic). Comptes Rendus Palevol 18(3), 353-366.

Slobodník, M., Přichystal, A. 2017: Provenience křřštálových artefaktů z aurignacké stanice Nová Dědina u Kroměříže na základě studia fluidních inkluzí. Přrehled výzkumũ 58(1), 9-18.

Škrdla, P., Bartík, J., Rychtaříková, T. 2015: Dvě koncentrace epigravettských artefaktů v Mohelně-Plevovcích. Přehled výzkumů 56(1), 9-29.

Škrdla, P., Bartík, J., Rychtaříková, T., Milo, P. 2019: Mohelno (okr. Třebíč). Přehled výzkumů 60(1), 163-164.

Škrdla, P., Knotek, P., Kuča, M., Rychtaříková, T., Eigner, J., Bartík, J., Vokáčová, J., Vokáč, M., Nikolajev, P. 2012: Neobvykle situovaná polykulturní lokalita Mohelno-Plevovce př́klad pronikání lidí do nitra Českomoravské vrchoviny. Acta Musei Moraviae, Scientiae sociales XCVII(2), 209-223.

Škrdla, P., Nejman, L., Bartík, J., Rychtaříková, T., Nikolajev, P., Eigner, J., Nývltová Fišáková, M., Novák, J., Polanská, M. 2016: Mohelno. A terminal Last Glacial Maximum industry with microlithic tools made on carenoidal blanks. Quaternary International 406A, 184-194.

Škrdla, P., Rychtaříková, T., Bartík, J., Nejman, L., Demidenko, Yu. E. 2018: Last Glacial Maximum paved stone structures from Mohelno-Plevovce, Moravia. Quartär 65, 51-61.

\section{Summary}

Stone structure E (labeled KSE) in Mohelno-Plevovce was discovered in early 2019 and excavated over several subsequent excavation campaigns permitted during short Hydroelectric Power Station maintenance breaks throughout the year 2019 (Fig. 1, 2). The excavation area is flooded for almost the entire time and time windows for archaeological excavations are very limited. This unusual set of circumstances requires specific excavation methodology. The field work must be swift, but precise at the same time - we propose to name this technique salvage-systematic excavation. Digging is possible for only several hours during the early morning before the area floods towards the middle part of the day. The excavated sediments are water-logged and not easy to dig, store, and transport for wet-sieving (Fig. 3). The excavation continues until the point when the trench becomes flooded. The following day, water in the trench must be bucketed out before the excavation resumes. Before transport to the wet-sieving station, the excavated sediments are labeled within individual sectors $(0.5 \times 0.5 \mathrm{~m})$ and layers ( $1^{\text {st }}$ layer is sediment above stones and gaps between individual stones, $2^{\text {nd }}$ layer is sediment below the stones). Some of the sediments are wet-sieved during the excavation on the shores of the water reservoir in the area of the fluctuating water level, however, most of the sediment is transported ca. $250 \mathrm{~m}$ out of reach of the fluctuating water level to be wet-sieved later. The shape of the stone structure is reconstructed from photographs utilizing the photogrammetry approach (Fig. 4). In this way, the area of KSE $(4 \times 5 \mathrm{~m})$ was completely excavated and all material was analyzed (except for microlithic tools). The second discovered structure (KSD) was covered by a "sarcophagus" made from local sediment in order to protect it from erosion before excavation is possible (Fig. 3: H).

The paved surface covers an area of $2.8 \times 3.6 \mathrm{~m}$ and is composed of 98 flat stones of local Gföld orthogneiss (thickness reaching 2-6cm). The second material of local origin - granulite accounts for approximately one fifth of the paving stones (thickness of the stones ranges $4-15 \mathrm{~cm}$ ). In total, construction of the KSE required transport of ca. $600-700 \mathrm{~kg}$ of stones from a distance of up to $250 \mathrm{~m}$. The spatial distribution of finds (both large and small finds), follows the boundary of the paved area except in the northeast corner, where distribution of finds overlaps the paved area. This is a similar pattern to that observed in KSB (Fig. 5, 6).

The raw material spectrum (Tab. 1) consists of prevailing local raw materials including rock crystal, quartz, plasma, and regional materials including smoky quartz and Krumlovský lestype chert, supplemented by imported erratic flint and radiolarite. The raw material spectrum is similar to KSB (Fig. 10). The technological spectrum is broader compared to both previously excavated structures (KSA and KSB) - includes cores, microcores and blanks that metrically fit the blade and microblade category. The prevailing tool type is the endscraper, however, some of the pieces were used as cores for carinated blanks. Some of the splintered tools were used as bipolar anvil cores for microlith blanks (Fig. 7). The microlithic tools have not been studied yet as it is a time-consuming process and magnification is required.

The finding of heavy-duty industry is a new discovery. These artifacts are larger and made on coarser rocks including quartz, granulite, and amphibolite - that served as site furniture (cf. Binford 1979) (Fig. 8, 9). They bear many traces of different uses - smoothing, abrasion, pounding, and flaking - and identification of their function presents a new research question. Similar observations were made at Grubgraben (Montet-White, Williams 1994).

Excavations in the above described harsh conditions will continue.

\section{Kontakty}

Jaroslav Bartík

Archeologický ústav AV ČR, Brno, v. v. i.

Čechyňská 363/19

CZ-602 00 Brno

adraj.bartik@gmail.com

\section{Petr Škrdla}

Archeologický ústav AV ČR, Brno, v. v. i.

Čechyňská 363/19

CZ-602 00 Brno

ps8a@seznam.cz

\section{Tereza Rychtaříková}

Archeologický ústav AV ČR, Brno, v. v. i.

Čechyňská 363/19

CZ-602 00 Brno

11bluezed@gmail.com 
Kamenná struktura E v Mohelnè-Plevovcích: nová výzva pro metodiku výzkumu • Bartík, J., Škrdla, P., Rychtař́ková, T., Demidenko, Y. E., Nejman, L. • Přehled výzkumů 61/1, 2020 • 47-57

\section{Yuri E. Demidenko}

Ferenc Rákóczi II Transcarpathian Hungarian Institute Kossuth square 6

UKR-902 00 Berehove

\&

Institute of Archaeology NASU

Geroyiv Stalingrada av. 12

UKR-042 10 Kyiv

yu.e.demidenko@gmail.com

\section{Ladislav Nejman}

School of Philosophical and Historical Inquiry University of Sydney

AU-2006 Sydney

\&

Archeologický ústav AV ČR, Brno, v. v. i.

Čechyňská 363/19

CZ-602 00 Brno

lnejman81@gmail.com 
